Winter 3-1-1999

\title{
It's Not Easy Being Green: Gender and Friendship in Eliza Haywood's Political Periodicals
}

Rachel Carnell

Cleveland State University, r.carnell@csuohio.edu

Follow this and additional works at: https://engagedscholarship.csuohio.edu/cleng_facpub

Part of the Literature in English, British Isles Commons

How does access to this work benefit you? Let us know!

Publisher's Statement

Copyright (C) 1999 The Johns Hopkins University Press. This article first appeared in EighteenthCentury Studies, Volume 32, Issue 2, Winter 1999, 199-215.

\section{Recommended Citation}

Carnell, Rachel, "It's Not Easy Being Green: Gender and Friendship in Eliza Haywood's Political Periodicals" (1999). English Faculty Publications. 24.

https://engagedscholarship.csuohio.edu/cleng_facpub/24

This Article is brought to you for free and open access by the English Department at EngagedScholarship@CSU. It has been accepted for inclusion in English Faculty Publications by an authorized administrator of EngagedScholarship@CSU. For more information, please contact library.es@csuohio.edu. 


\section{$\int_{\text {T's Not Easy Being Green: }}$ GeNDER AND FRIENDSHIP IN ELIZA Haywood's Polttical Periodicals}

\section{Rachel Carnell}

Habermas describes the evolution in eighteenth-century Britain of a public sphere of private individuals whose "public use of the rational faculty" would enable a critique of government actions and ultimately pose "a threat to any and all relations of domination." "This emergent sphere of rational debate, however, did not merely consist of private men engaging in public use of their reason, but required a further humanistic bond between individuals "who were psychologically interested in what was 'human,' in self-knowledge and in empathy" (50); the public sphere relied, in other words, on an ideal of friendship between men. This model of affective humanism accords with Jacques Derrida's analysis of the importance of friendship to Western theories of politics. Citing Montaigne's allusion to Aristotle in the ironic reference "O mes amis, il n'y a nul amy," ${ }^{2}$ Derrida suggests that the idea of community is invoked by even the simple act of address: "We would not be together in a sort of minimal community...speaking the same language or praying for translation within the horizon of the same language...if a sort of friendship had not already been sealed before any other contract" $(636) .^{3}$ From this minimal foundation for community, Derrida underscores how traditional Western political philosophy has linked a certain figure of friendship "to virtue and to justice, to moral reason and to political reason." By reminding us of the "essential and essentially sublime figure of virile homosexuality" that has traditionally inscribed the polis, Derrida also points to the "double

\footnotetext{
RACHEL CARNELL, Assistant Professor of English at Cleveland State University, has published articles in Eighteenth-Century Fiction and NineteenthCentury Literature. She is currently completing a book-length study of the relationship between eighteenth-century political discourse and the rise of the novel.
}

Eighteenth-Century Studies, vol. 32, no. 2 (1998-99) Pp. 199-214. 
exclusion that can be seen at work in all the great ethico-politico-philosophical discourses on friendship, namely, on the one hand, the exclusion of friendship between women, and, on the other hand, the exclusion of friendship between a man and a woman" $(642){ }^{4}$

Derrida's identification of this exclusion of women and of heterosexual friendship from the traditional Western concept of the polis is consistent with Carole Pateman's analysis of the way women are excluded from the social contract by their prior subordination under a monogamous (hetero)sexual contract. ${ }^{5}$ Habermas's analysis of the public sphere also offers insight into the way that the domestic sphere was simultaneously essential to and excluded from the political public sphere. Although he describes how private men needed the humanizing conceptions of themselves that they gained through their participation in family life in order to function as members of a fraternity of rational public voices, Habermas observes that the wives and other household dependents on whom the men depended to nurture their affective humanism "were [themselves] factually and legally excluded from the political public sphere." ${ }^{\prime \prime}$ Habermas suggests, however, that women may not have been completely excluded from public sphere debates insofar as there was a parallel sphere of literary discourse and debate in which "female readers and servants often took a more active part...than the owners of private property and family heads themselves" (56). This "literary public sphere" seems to be the province of women readers; it also seems to be, in particular, a sphere of novels: Habermas describes how the novelist Samuel Richardson "wept over the actors in his novels as much as his readers did" (48). This reference to the literary public sphere, however, is confusing because Habermas does not consistently maintain the distinction between the literary and the political public spheres; ${ }^{7}$ moreover, he conflates the "literary" with the genre of the novel, a genre that Dustin Griffin describes as frequently excluded from the networks of political patronage that flourished during the eighteenth century. ${ }^{8}$

Despite the difficulties that faced both women and novelists in securing traditional forms of political patronage, we should not assume that this prevented either group from actively engaging in literary-political commentary during the first decades of the eighteenth century. Catherine Gallagher describes the early part of the century as "an extraordinary moment in the history of English women's writing, a moment when party politics, fiction, the literary marketplace, and feminine sexuality became intricately entangled." As the century progressed, however, the obvious overlap between novelistic discourse and politics gradually diminished (Gallagher, 520), and by mid-century, as Nancy Armstrong observes, domestic fiction "began to deny the political basis for its meaning." ${ }^{10}$ Given the apparent split between novelistic and political discourse by the 1740s, it is not surprising that Habermas should refer to Richardson as an example of a novelist whose literary productions helped to generate the affective humanism of the public sphere. ${ }^{11}$ However, in categorizing the novel as the apolitical province of women and the theater along with the periodical as the political province of men, ${ }^{12}$ Habermas necessarily overlooks not only the political import of early British novels but also the ways in which the literary and political discourses overlapped in other eighteenth-century texts, including periodicals written by or primarily addressed to women, such as Richard Addison and Jo- 
seph Steele's The Spectator (1711-12) and Eliza Haywood's The Female Spectator (1744-46) and The Parrot (1746).

Kathryn Shevelow explains how eighteenth-century periodical literature was crucial in constructing a literary public sphere that seemed both to welcome and to exclude women. ${ }^{13}$ Ros Ballaster articulates the paradox posed by periodicals addressed particularly to women: "Does the women's magazine provide a women's perspective on a political and social order from which they are generally alienated, or an alternative female community that centers on...family, home and love?" ${ }^{14}$ Ballaster explains that in the early part of the eighteenth century, female writers, such as the anonymous author of The Female Tatler (1709), did not doubt their right to articulate "veiled references to the sexual and political misdemeanours of the rich and powerful of Court and Commons" (58), although by the 1770s "any attempt to introduce 'politics' into the domestic environs of its women readers was met with immediate and vociferous complaint" (56). Given the chronology that Ballaster outlines, it makes sense that in her periodicals from the mid-1740s, the novelist Eliza Haywood would enact the quandary of a women writer at a moment in history when the border between literary and political discourses was becoming increasingly marked by gender difference. While scholars have recently begun to recognize the political overtones of Haywood's "scandalous" domestic fiction from the 1720 s, few have considered the political import of her periodicals from the 1740s, both of which she describes as political commentary. ${ }^{15}$ I will argue that in The Female Spectator and The Parrot Haywood protests against the nascent gendered split, in the 1740s, between literary genres perceived as political and those perceived as domestic. Moreover, I will show that Haywood articulates her objection to this split through a refiguration of the forms of friendship that Derrida describes as being traditionally excluded from the political realm.

\section{SPECTATORS AND FEMALE SPECTATORS}

When Michel de Montaigne, former magistrate and future mayor of Bordeaux, inscribes the essay "De l'amitie" to the memory of his friend and mentor, La Boétie, there is no doubt of the public, political resonance of these lines penned in the seclusion of his domestic château. Montaigne's Essais-his idiosyncratic "attempts" or reflections on such topics as friendship, education, solitude, imagination, and the public good-represent a seamless interplay between domestic and political concerns; he even describes the private turret from which he writes as being simultaneously his "conjugal, filial, and civil community" (la communauté et conjugale et filiale et civile) ${ }^{16}$ For the man credited with the invention of the personal essay, the ability to move freely between the domestic, private, and political spheres was no doubt crucial to the public bond he invoked by addressing his readers as friends, a connection all the more poignant for his simultaneous assertion of the impossibility of friendship. More than a century later in London, Joseph Addison and Richard Steele evoked a similar bond between themselves and their readers by having their Spectator describe a characteristic he assumes is shared by the entire reading public: "I have observed that a reader seldom peruses a book with pleasure until he knows whether the writer of it be a black or a fair man, of a mild or choleric disposition, married or 
a bachelor." ${ }^{17}$ This act of address constructs what Derrida would describe as a "minimal community" between Spectator and readers, based on the presumably universal human characteristic of wanting to know something about the author of the books we read.

Ironically, it is through this very assertion of connection to the reader that the Spectator brings to light the conundrum inherent in the Western conception of friendship - that to name someone a friend always requires an act of selection that necessarily excludes others, or as Derrida explains: "There is no belonging or friendly community that is present, and first present to itself, in act, without election and without selection." ${ }^{18}$ In the Spectator's case, the characteristics of skin color, marital status, and temper might seem to denote minor distinctions between otherwise equal individuals within the public sphere, yet these differences are only insignificant within a broader rubric of sameness. The difference between fair skin and bronze may seem innocuous, but between native European and African or West Indian, difference overpowers sameness in an economy enriched in part by profits from imperialism and the slave trade. Marriage status may make little difference to an educated, financially solvent, Anglican male, but it makes every difference precisely within the rubric the Spectator leaves out of his list of binary opposites: that of gender difference.

The exclusionary implications of the Spectator's first act of universalizing address are further emphasized by his self-described tendency to taciturnity, his disinclination to open his lips, except in the company of his own club. ${ }^{19}$ Haywood's Female Spectator, by contrast, describes herself as someone who has, in the past, been too inclined to socialize: in the opening pages of that periodical, she describes herself as having spent her youth "engross'd by a Hurry of promiscuous Diversions." Moreover, rather than being silent about her personal history, she intends to speak freely of it in order "that the Publick may reap some Benefit from it." ${ }^{20}$ By defining herself through her difference from conventional morality while asserting the universality of the moral lessons derived from her particular experience, Haywood defines her narrative strategy in opposition to that of her "learned Brother of ever precious Memory" (1:2), who articulates a tone of universality while confessing his preferences for isolation and exclusion. Haywood's narrative strategy also reflects the difference in the reception she apparently anticipates from her periodical. Male essayists who were not independently wealthy (as was Montaigne), faced the challenge of negotiating the complexities of political patronage and could never assume their work would be read simply as apolitical, personal reflection. The Spectator insists in the first issue: "I never espoused any party with violence, and am resolved to observe an exact neutrality between the Whigs and the Tories, unless I shall be forced to declare myself by the hostilities of either side." ${ }^{21}$ By contrast, in order to claim the political relevance of the anecdotes she relates in The Female Spectator, Eliza Haywood must stage an epistolary debate about her very ability to write political commentary.

In the first issue of The Female Spectator, a periodical that she issued in monthly six-page "books" or issues between 1744 and 1746, Haywood outlines her interest in being "in some measure both useful and entertaining to the Publick" by satisfying her readers' desire of to be "made acquainted with other People's Affairs" and by "at the same Time teach[ing] every one to regulate their own" (1:3-4). 
Her desire to gratify the general public's interest in gossip might place this periodical squarely in the realm of the personal or apolitical, yet she also borrows language from the world of political intrigue when she describes how she has placed spies all over London, France, Rome, and Germany so as not to miss any of "the Mysteries of the Alcove, the Cabinet, or Field" (1: 6). This promise of political information, however, is belied by the actual content of subsequent issues, which focus on amorous intrigues in the style of scandal chronicles, similar to much of Haywood's short domestic fiction from the 1720s. In the first two decades of the period, as Catherine Gallagher has explained, the very claim to writing merely amatory fiction (a somewhat disingenuous defense frequently used by women writers who were arrested for seditious libel) represented a lure to an audience seeking political scandal, in an age when such scandal seemed essential to publisher's profits. By the mid-1740s, however, Haywood, whose own earlier fiction was obviously written to appeal to an audience interested in both sexual and political scandal, was forced to confront the increasingly gendered disjunction between literary genres recognized as political and those seen as merely domestic.

The Female Spectator calls attention to this distinction when she prints an ostensible reader's complaint that she has not fulfilled her stated purpose of publishing a periodical "fit for the polite Coffee-Houses or to satisfy Persons of an inquisitive Taste," but instead has penned "Lucubrations...[which are but] fit Presents for Country Parsons to make to their young Parishioners; - to be read in Boarding-Schools, and recommended as Maxims for the well regulating private Life" (2: 121). Haywood realizes that even when Addison and Steele were commenting on women's deportment, dress, and moral intrigue (affairs which might be considered to be of interest only to women in the confines of the domestic sphere), they still could be assured that their publication would be considered appropriate for the "polite CoffeeHouses" if only because of their frequent allusions to conversations overheard at Will's, Child's, or St. James's. She also demonstrates how Curioso Politico, an impudent correspondent who first addresses her rudely as "Vain Pretender to Things above thy Reach!" (2: 117), cannot separate his criticism of her writing from his criticism of her as a woman who dared to challenge the boundaries of the literary-domestic sphere. "Tho I never had any very great Opinion of your Sex as Authors," he writes, "yet I thought, whenever you set up for such, you had Cunning enough to confine yourselves within your own Sphere" (2: 117-18).

In response to Curioso Politico's insulting act of address, Haywood challenges the assumption that the best way of commenting on the political public sphere would be to repeat the factual reports of "News Mongers" describing details "such as Armies marching-Battles fought,-Towns destroyed,-Rivers cross'd, and the like" (2: 123). Eventually she dismisses the nuances of even high political debate as but the mindless intricacies of children's games:

I GRANT some Turns and Counter-Turns in Politics have been too abstruse to be accounted for by the Rules of common Reason, and no way to be fathom'd but by that Intelligence he wants me to receive from the Cabinets where they were hatch'd;-and yet perhaps, if once revealed, there would appear so little in them, that one might justly 
compare them to the Knots Children tye at School in Packthread, only to puzzle one another to undo again. (2: 124)

Haywood's dismissal of high political discourse as mere child's play marks her attempt to discount an increasingly male discourse of political commentary, a discourse for which she will offer a substitute female model in the subsequent issue of her periodical.

In "A DIALOGUE between An English and a Hanoverian Lady" (2: 135), which comprises the bulk of the ninth issue, Haywood not only reasserts her claim to a political voice but challenges the very figure of homosocial friendship so fundamental to the discourses of the political public sphere. This twenty-three page debate features two well-informed women rationally and politely disagreeing whether the current Hanoverian monarch gains more by ruling England than the English do by having him rule them. Each speaker cites relevant legal, economic, and cultural reasons to support her cause, confirming the introductory remarks of the ostensible witness to the debate, one A.B., a man whose educational status may be inferred by his very initials: "I must confess, my Reason yielded to them both by Turns:-I was convinced, confuted, and convinced again as often as either of them spoke" (2: 133). While Haywood is clearly balancing the misogyny of Curioso Politico with A.B.'s admiration for the two women's capacity for rational debate, she does not rely merely on the flattery of a possibly fictive male correspondent to make the case for women's right to participate in the political public sphere; Haywood is also constructing a model of polite, mannered public debate that contrasts sharply with the more strident pamphlet wars that marked, for example, the anti-Jacobite tracts from the same period. ${ }^{22}$ In herself complimenting the "Moderation and Sweetness" used by the debating women, Haywood denigrates those "who cannot hear themselves contradicted without Virulence and bitter Speeches" (2: 158).

In addition to sketching a model for female-female friendship that could potentially re-shape public sphere debate, ${ }^{23}$ Haywood also demonstrates an interest in defining a model for public, rational epistolary exchange between a man and a woman that would not be misunderstood as apolitical romance. In response to Curioso Politico's first insulting line of address, Haywood, politely thanks him for drawing his concerns to her attention; when she has finished defending herself from his attacks, she writes that she trusts her response "will be look'd upon as a sufficient Answer to all the Objections Mr. Politico has started for the present, and hereafter perhaps we may be better Friends" (2: 126). While there is hint of dark irony in her address of friendship to a correspondent who may only be a creation of her own imagination (and who, moreover, has already insulted her), Haywood's politely mannered response describes a model for rational friendship between a man and woman that might be included within the political public sphere, even as the fraught "perhaps" shows her awareness of the cultural forces that would render such an epistolary bond extremely unlikely.

As if further considering the possibility of joining women's and men's voices together in a homogeneous voice of rational observation, Haywood hints in the last issue of The Female Spectator (March 1746) that the "little Cabal, " as she 
terms the female authors of her periodical, will be replaced by a "League" of men and women who will jointly author the next publication. Her interest in translating her female cabal to a heterogendered league describes a move from an illicit political grouping to a more legitimate one. ${ }^{24}$ However, this androgynous league never comes into existence: in her subsequent periodical, The Parrot (begun five months later), Haywood chooses not to seek the harmony or sameness of a universalized male-female voice but instead to articulate more strongly her position of difference. She reappears as not human, but as foreign, nonhuman, and gendered simultaneously as both male and female, occupying a precariously liminal narrative position whose perspective obliges reflection not merely on the marginalized position of women but on the more general mechanisms of alienation and exclusion operating within the dominant political discourses of the public sphere.

\section{THE POLITICS OF OTHERNESS}

In the opening issue of The Parrot, Haywood defines herself as "a Bird of Parts" or a bird who has experienced the richness of life in different countries, among people of all social classes: "I cannot well be otherwise, considering the various Scenes of Life I have gone through,--the many different Nations I have lived among,--the Conversation I have had with all Degrees of People." ${ }^{25}$ Moreover, this "Bird of Parts," echoing the typically masculine label "man of parts" represents a narrator who is described on the title page as being enunciated "By the AUTHORS of The Female Spectator"-i.e., by a group of women. After finally referring to itself as "he" in the second issue, the Parrot aligns himself with a line of male inheritance, yet he continues to draw attention to his alien or nonhuman nature at the same time that he underscores the continuity of his lineage from his forefathers:

In the first Place, I am a Parrot;-my Father, Grandshire, great Grandshire, and so back for near six thousand Years, were all Parrots; and if Antiquity be looked upon as a necessary Qualification for a great Name, it is easy to make appear, even from your own Chronology, that our Race was prior to Adam, the first Man. (no. 2)

Continuing to focus on his difference from his readership, the Parrot then defines his species as "free Denizons of Earth and Air" while he reminds his human readers: "you....were degraded from your native Dignity,--turned out of your first Mansion" (no. 2).

The Parrot's articulation of his simultaneous sameness and difference from men has the effect of inviting his readers into an epistolary intimacy or friendship with him and yet simultaneously warning them away. In contrast to Addison and Steele's Spectator, who stresses his taciturnity, the Parrot underscores his inability to hold his tongue:

My great Facility in learning the Languages, joined with a happy Memory, and a voluble Delivery, doubtless it was that rendered me so acceptable among Strangers, and my Conversation so agreeable on a first Acquaintance:-Certain it is, that could I have been as se- 
cret as I was accounted learned and eloquent, I might have been entrusted in the Quality of an Interpreter to a first Minister, (as some I have known who understood no other than their Mother-Tongue;) but, to my very great Misfortune, I never was blest with the retentive Faculty;-I was sure to report whatever I heard, and not seldom to those in whose Presence I ought to have been most cautious. (no. 1)

In contrast to career politicians and others who know the trick of when to keep silent, the Parrot attempts to befriend its audience by stressing its disingenuousness: "You see, good People, what you are to expect:-I deal ingenuously with you; therefore, if any one among you communicates to me what he would not have a Matter of universal Chit-Chat, let him blame himself when he finds it is so" (no. 1). The Parrot's attempt at inculcating friendship or empathy between himself and readers, however, ultimately founders precisely on the prized quality of truthfulness, which renders an invitation to friendship and, simultaneously, a threat of betrayal to all but the morally pristine: "the truly Wise and Virtuous have nothing to apprehend from me" (no. 1). ${ }^{26}$

The Parrot further develops not only his potential to betray but also his difference or otherness when he reflects on the difficulties he has endured because of his color:

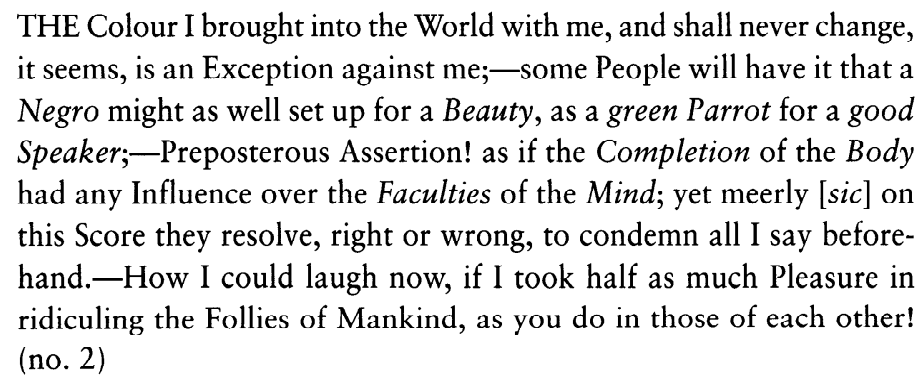

Recalling the Female Spectator's complaints against not being taken seriously because she is a woman, it is logical to hear the male parrot as mouthpiece of the author(s) of The Female Spectator protesting against women's inability to be taken seriously in the political public sphere. And yet, by establishing a parallel between the dominant culture's refusal to acknowledge the aesthetic virtues of blacks and its refusal to acknowledge the verbal eloquence of green parrots, Haywood allows the color and species of her feathered persona to stand for more than just her sex and indeed to stand for a broad spectrum of differences from the dominant bourgeois, white, Anglican, male public sphere, whose interests Kathleen Wilson has described as defined by "gender, race, productivity, and profits." 27 The difficulties posed by "being green" represent the broader problem of exclusion from a public discourse whose images of friendship and sameness tantalizingly suggest the potential for universal inclusion.

The Parrot, unlike The Female Spectator, could never be mistaken as a periodical of merely domestic anecdote; instead, Haywood has apparently overcome her previous disinclination to engage in the work of "News Mongers," for she ends each issue of The Parrot with a "Compendium of the Times," written as "A LETTER to a Friend in the COUNTRY." In narrating the compendia, Haywood, who seems only to be parroting (although not necessarily in the Parrot's voice) Newspaper 
accounts, reveals a marked interest in the fate of Highland Jacobites facing trial during the months that the periodical was being published-August and September 1746. While the letters to this friend in the country do not express any directly pro-Jacobite sentiments, Haywood never fails to list the names of those facing trial or to describe the charged emotions of spectators witnessing the executions of those found guilty. For example, in what appears to be an afterthought, Haywood includes in the postscript to her first Compendium, the account of a beautiful and much loved young Lady whose fiancé was "one of those unhappy Gentlemen" who had been arrested for high treason. In relating how this beautiful young Lady suddenly died of grief, after witnessing her fiancé's execution, Haywood refrains from moralizing except to conclude: "the Story very much affected me, as I doubt not but it will you" (no. 1). Although she does not presume perfect empathy between herself and all of her readers, Haywood addresses the particular friend in pastoral exile as someone who shares a common interest in and sympathy for those Jacobites facing trial. These highly selective news reports recall Haywood's dismissive comments in The Female Spectator about merely factual news accounts and underscore the subjective nature of apparently objective and rational public reporting. In setting up this multivalenced mode of address in which certain comments may sound innocent to the average reader but carry a particular political message to a special segment of readers and subscribers, Haywood introduces a third paradigm of friendship excluded from the public spherethat between supporters of marginalized political factions.

The possibility that Haywood held Jacobite sympathies is suggested by her 1749 arrest for seditious libel, as well as by the very language of her Parrot narrator. ${ }^{28}$ The color green, on which he so eloquently rhapsodizes, was associated so strongly with the oak bough of support for the exiled Stuarts that in 1717 and 1718 people were arrested for wearing a sprig of green..$^{29}$ The Parrot's insistence on the chronology of his paternal line also emblemizes the arguments of lineage the Jacobites used to discount Hanoverian claims to monarchy. ${ }^{30}$ Carefully veiling her voice behind the triple frame of green parrot, author of The Female Spectator, and auditor of secondhand accounts of Jacobite executions, Haywood expresses her political stance through a level of opacity that contradicts the rational transparency that supposedly defined the Enlightenment public sphere. After describing its frustration at not being taken seriously because of its color, Haywood's parrot then muses on the citizens of "a certain Nation, who notwithstanding their Reputation and good Sense in some Things, have rendered themselves pretty remarkable for their liking and disliking to an Excess." The Parrot reflects on the cruelty of a certain national leader-Oramwho "laughed very heartily to see the several Limbs and mangled Carcasses lye spread upon the Field of Action" (no. 2).

In further developing her position vis-à-vis this coded political leader, Haywood aligns him with a sadistic Roman emperor, clearly an allusion to "the Butcher of Culloden" (the Jacobite epithet for the Duke of Cumberland), thus implicitly contrasting him with a more humane Caesar or Augustus, as Jacobites preferred to view Charles Edward Stuart: ${ }^{31}$ 
it is said, delighted himself with plucking out the Eyes of these Insects; and I must acknowledge that his Behaviour appeared to me at first to have somewhat in it of Cruelty; but when I considered how much he is extolled for Compassion, Generosity, and every human Virtue, I presently accused my premature Supposition, and concluded that these Wretches did not only deserve their Fate, but also that Oram, in his great Wisdom, knew it was better even for themselves to be divested of those Limbs, which while they were Master of, enabled them to be vexatious to those of a superior Species. (no. 2)

Haywood is probably alluding here to the propensity for cruelty demonstrated by the Duke's military defeat and the Crown's executions of Highland Jacobites; she may also be referring more specifically to the recently introduced legislation for disarming the Highlanders, which she mentions in the subsequent Compendium of the Times, a bill that would in fact divest Jacobites of "those Limbs" (in this case, both literal limbs as well as "arms") that "enabled them to be vexatious" to the English government. In the Compendium itself, Haywood seems not to express an opinion about the legislation but only remarks, as ostensibly unbiased witness to what she has heard: "I hear there have been some Debates Pro and Con on the Affair" (no. 2). This opaque criticism of government policy, a critique not legible through either Haywood's Compendium or the Parrot's narrative but only available through the palimpsest effected by reading the two adjacent sections in tandem, challenges not only the possibility of gleaning truth from a single, apparently unbiased narrative but also the possibility of a bond of trust or friendship between an outsider (whether a woman or a Jacobite or any of many other marginalized groups) and the dominant voices within the political public sphere.

In describing the "political imaginary" of mid-eighteenth-century Britain, Kathleen Wilson explains that "the national community constructed by the newspaper and periodical press.... was imagined to consist of free, flourishing, and largely, though not exclusively, white male British subjects within the locality, nation, and empire." Thus, the status of "women, slave and free Africans, Jews, servants, Catholics, laborers, and so on" within the newspaper press "was usually implicit at best, extrapolated through the claims to status of the male middling sorts or their betters." 32 Implicit within this norm of the "male middling sorts" is, as I have already argued, a logic of sameness that also assumes the possibility of rational friendship among its members. Haywood challenges the dominant public self-image that more traditional political periodicals of the period were helping to construct by continuing to undermine the possibility of true friendship between her Parrot persona and his (her) readers. While all the rest of London seems to find the trials and executions entertaining, she insists that "POOR Poll is very melancholy,-all the Conversation I have heard for I know not how long, has been wholly on Indictments,-Trials, Sentences of Death, and Executions:- Disagreeable Entertainment to a Bird of any Wit or Spirit." To those around her who seem to find entertainment in it, she pleads: "is there no Pity due to the living Relatives of those unhappy Persons, who, though innocent, must suffer in their Kindreds Fate?" (no. 4). Again at the end of the eighth issue, she insists on her position as "alien...in these Kingdoms" (no. 8). 
In the ninth and final issue, Haywood's parrot publishes a letter from another parrot, one Amicus Veritas, who relates the story of a jeweler who so trusted his untrustworthy pet parrot that he had his maid put to death for stealing diamonds that the parrot had actually taken. This anecdote, which has the effect of further alienating readers from both parrot narrators, characterizes parrots (or Jacobites) as unwitting kleptomaniacs, an image consistent with the prevailing English view of them as "persons without honour or scruples, often outsiders like the hated Irish, always ready to engage in detestable crimes." ${ }^{33}$ Although clearly recognizing himself as "other" in the eyes of the dominant culture, ${ }^{34}$ Amicus Veritas does not grasp that it is precisely because of his otherness that his voice will be excluded from a public sphere theoretically devoted to seeking truth through rational debate. After acknowledging parrots' unfortunate tendencies to kleptomania, Amicus insists that his species has "one excellent Quality, which is, that of free speaking." He then ends his letter with an exhortation for parrots to protect the liberty and honesty of the country: "let then...these Birds, since no other will undertake the Task, correct the false and ridiculous Rumours of Coffee House Politicians, as well as the lying Legends which issue from the Press, and be the Pipes, through which the sacred Oracles of Truth may be convey'd" (no. 9). Haywood's narrator, in responding to his old friend and Friend of Truth, admits that while parrots, "sometimes do a great deal of Good by reporting indiscriminately, and without Partiality to any Party, Side, or Person, whatever we hear," there is also danger in speaking openly: "where there is no Confinement, no Padlock on the Tongue or Pen, what Lengths might both run into" (no. 9). The Parrot's reference to the "Lengths" to which "Tongue or Pen" might lead suggests the danger that dissenting factions might pose to the legitimate government; at the same time, the passage also evokes the danger or "Lengths" that "both" the government and those who dare not padlock their own partisan thoughts "might run into." Once again, Haywood challenges the dominant public sphere image of trusting friendship by alluding to those persons whose ideological or political differences exceed the boundaries of sameness required for participation in public political debate.

Insisting on the potential dangers of free speech, Haywood's Parrot narrator ends the final issue with a plea for passive obedience that again casts a doubt on this not quite trustworthy feathered mouthpiece: "Obedience is due to our Rulers and Governors, not only to such as are wise and good, but also to the forward and indiscreet, provided, at the same time, that they have a lawful and natural Claim to the Dignity they enjoy" (no. 9). This plea for passive obedience, which ostensibly articulates allegiance to the sitting monarch, however "forward" or "indiscreet," would bring to mind the widely publicized 1709 treason trial of Henry Sacheverell, who was arrested for preaching a doctrine of passive obedience that was construed as opposition to Revolution Principles of 1688. The faintly treasonous overtone of this plea for obedience is reinforced by Haywood's suggestion that loyalty is owed the House of Hanover, not for its skill or merit, but merely because of its "lawful and natural Claim," a claim whose naturalness or lawfulness any loyal Jacobite would have disputed. ${ }^{35}$ The ironic opacity of the last paragraph, professing loyalty at the same time that it conveys a more subtly oppositional message, once again undermines the possibility of the open and rational debate so prized by the dominant voices of the eighteenth-century English public sphere and brings to mind the question posed by twen- 
tieth-century critics of Enlightenment rationalism: Should we view the Enlightenment public sphere through Horkheimer and Adorno's cautionary appreciation of the hegemonic potential of the force of reason or through Habermas's more explicit confidence in the rational "universalistic discourses" that contained within them a "potential for self-transformation"? 36

A major difficulty in understanding the legacy of the Enlightenment, of course, lies not merely in the opacity or transparency of the texts themselves but in the more fundamental question of which texts comprise the canon of Enlightenment thought. In tracing the history of the figure of friendship through traditional works of Western philosophy, Derrida describes his strategy as not "to submit to their authority or to confirm a hierarchy but, on the contrary, as it were, to question the process and the logic of a canonization which has established those discourses in a position of exemplary authority." ${ }^{37}$ I suggest that part of this process of questioning the logic of canonization should include a challenge to our usual methods of distinguishing high philosophical-political discourse from fictional, journalistic, or other discourses typically perceived as either ephemeral or simply apolitical. Derrida muses on how we are to "shake up the most traditional concept of historicity" vis-à-vis "the history of friendship" (his emphasis); he discerns the "tremors" of "not yet" within the "GrecoRoman model" of friendship, which he believes "bears within itself, nevertheless, potentially, the power to become infinite and dissymmetrical" (290). Another way of supplementing "the traditional history" of friendship, family, and the state, however, would be to read the periodicals and novels of popular, noncanonical authors such as Eliza Haywood, whose participation in and simultaneous critique of the discourses of the dominant public sphere elucidate the threat her voice posed to its more mainstream participants. In particular, the history of the condescension with which Haywood's writing was received-from Pope's famous allusion to her in The Dunciad to a range of twentieth-century criticism that until recently saw the only "scandal" in her works as its sexual content-is also a history that has continually insisted on dismissing her work from the political public sphere to an apolitical literary sphere of scandalous domestic anecdote. ${ }^{38}$

Haywood's open protest in The Female Spectator against the relegation of her work to the domestic sphere of "Country Parsons" and "Boarding Schools" demonstrates her keen awareness of the increased difficulty, by the mid1740 s, of asserting the political import of domestic narrative, despite the clear overlap between political and domestic intrigue in the early decades of the century. The narrative personae in her periodicals also articulate her frustration at a political public sphere that excluded texts not only because of their genre but because of the gender and political partisanship of their author. It is difficult to know for certain why Haywood ceased writing periodicals after the last issue of The Parrot, but she may have decided that if she was going to be received as a writer of purely domestic anecdote, then she should turn back to genres in which she might be taken seriously and focus on what critics have traditionally referred to as her "respectable" domestic fiction and conduct books of the late 1740s and 1750s (in contrast to her "scandalous" earlier fiction), texts whose own political overtones have not yet been fully recognized. In her popular novels The Fortunate Foundlings (1744), The History of Miss 
Betsy Thoughtless (1751), and The History of Jenny and Jemmy Jessamy (1753), for example, Haywood crafts narrative images of friendship, trust and betrayal between men and women and between fathers and children that I would suggest further challenge the paradigm of male-male friendship as a sole factor in determining a man's position within the public sphere.

Haywood's skill in manipulating the boundary between literary and political discourse must, of course, be considered in light of what Catherine Ingrassia describes as her interest in ensuring "the broadest consumer appeal." ${ }^{39}$ As a woman writer who attempted during her thirty-seven-year career to turn a profit through a variety of positions, including playwright, novelist, translator, periodical writer, conduct book writer, bookseller, and anonymous distributor of political pamphlets, Haywood necessarily would have been concerned with the economic implications of the literary and political genres she chose to work in. However, looking beyond her commercial concerns, we must also must appreciate her challenge to the foundations of a political public sphere dependent on an image of bourgeois, Anglican, male-only friendship, an image, moreover, that two and a half centuries later, has not fully been shaken. ${ }^{40}$ A reconsideration of Haywood's oeuvre could yet help us establish new paradigms for the Enlightenment public sphere's ongoing "self-transformation," even as her work continues to provide crucial testimony to the intractability of its dominant discourses. ${ }^{41}$

\section{NOTES}

1. Jürgen Habermas, The Structural Transformation of the Public Sphere: An Inquiry into a Category of Bourgeois Society, trans. Thomas Burger (1962; Cambridge, MA: MIT Press, 1989), 54.

2. Jacques Derrida, "The Politics of Friendship," The Journal of Philosophy 85 (November 1988): 632-44, 632. Derrida cites Montaigne from "De l'amitié" in Essais, bk. 1 (Paris: Pléiade, 1959), 226.

3. Derrida repeats this phrase almost verbatim in his book-length elaboration of his preliminary essay, The Politics of Friendship, trans. George Collins (London and New York: Verso, 1997), 236.

4. See also Derrida, Politics of Friendship, 279.

5. Carole Pateman, The Sexual Contract (Stanford: Stanford Univ. Press, 1989), 3.

6. Habermas, Structural Transformation, 56.

7. Elizabeth Heckendorn Cook, Epistolary Bodies: Gender and Genre in the Eighteenth-Century Republic of Letters (Stanford: Stanford Univ. Press, 1996), 11.

8. Dustin Griffin, Literary Patronage in England, 1650-1800 (Cambridge: Cambridge Univ. Press, 1996), 10-11. Griffin also indicates that a few women novelists, such as Charlotte Lennox, managed to receive patronage at certain times during their career. Deborah Payne's work on women and patronage further explains the severe economic disadvantages women faced in their generally less successful attempts to secure patronage; see Payne, “'And Poets Shall by Patron-Princes Life': Aphra Behn and Patronage," in Curtain Calls: British and American Women and the Theater, ed. Mary Anne Schofield and Cecilia Macheski (Athens, OH: Ohio Univ. Press, 1991).

9. See Catherine Gallagher, "Political Crimes and Fictional Alibis: The Case of Delarivier Manley," Eighteenth-Century Studies 23 (1990): 502-21, 504. For a discussion of the differences between eighteenth- and nineteenth-century articulations of the split between the literary and political public spheres, see my "Feminism and the Public Sphere in Anne Brontë's The Tenant of Wildfell Hall," NineteenthCentury Literature 53 (June 1998): 1-24. 
10. Nancy Armstrong, Desire and Domestic Fiction (Oxford: Oxford Univ. Press, 1987), 21.

11. As this was the standard interpretation of Richardson at the time when Habermas was writing his Structural Transformation, I do not mean to suggest that he would have had access to any alternative interpretations. For further insights into overlapping literary and political discourses in Richardson's text, see Cook's Epistolary Bodies, 71-113, and my "Clarissa's Treasonable Correspondence: Gender, Epistolary Politics, and the Public Sphere," Eighteenth-Century Fiction 10 (April 1998): 269-86.

12. Habermas, Structural Transformation, 59-61.

13. Kathryn Shevelow, Women and Print Culture (London: Routledge, 1989), 4.

14. Ros Ballaster, Margaret Beetham, Elizabeth Frazer, and Sandra Hebron are the joint authors of Women's Worlds: Ideology, Femininity and the Woman's Magazine (London: Macmillan Education, 1991), although they indicate in the preface that Ros Ballaster is largely responsible for chapter two, "Eighteenth-century Women's Magazines," from which I am quoting (49-50). Kathryn Shevelow also comments on the way that periodical essays help to construct the domestic woman in Women and Print Culture, although she focuses more on gender politics than on the specific political content of theses periodicals.

15. In elucidating amatory fiction's relationship to party politics, Ros Ballaster delineates the obvious satire of the South Sea Bubble in Haywood's Memoirs of a Certain Island Adjacent to the Kingdom of Utopia (1727) and Haywood's anti-Walpole stance in The Adventures of Eovaai (1736); see Ballaster, Seductive Forms: Women's Amatory Fiction from 1684 to 1740 (Oxford: Clarendon Press, 1992), 15358. However, aside from these two obvious allusions to party politics, Ballaster describes the bulk of Haywood's work as "part of a struggle for power and, more particularly, a gendered conflict over the interpretation of the woman's body as amatory sign" (174). Ballaster also ignores the political import that Haywood claims for The Female Spectator, which she describes as containing "no veiled references to the sexual and political misdemeanors of the rich and powerful" (Women's Worlds, 58). For all their focus on social history, Helen Coon ("Eliza Haywood and the Female Spectator," Huntington Library Quarterly 42 [winter 1978]: 43-55) and Deborah Nester ("Representing Domestic Difficulties: Eliza Haywood and the Critique of Bourgeois Ideology,” Prose Studies 16 [August 1993]: 1-26), overlook the specific political allusions in The Female Spectator. The Parrot has scarcely been analyzed by scholars. Catherine Ingrassia's observations in "Additional Information about Eliza Haywood's 1749 Arrest for Seditious Libel" establish the need for broader recognition of Haywood as "producer and distributor of surprisingly political texts in a heretofore unrecognized way." Sec Notes and Queries 242 (June 1997): 202-4, 202. Ingrassia's Authorship, Commerce, and Gender in Early Eighteenth-Century England: A Culture of Paper Credit (Cambridge: Cambridge Univ. Press, 1998, forthcoming) further elaborates the way that Haywood negotiates the "fundamental generic instabilities that characterize this literary period-was fiction 'political'? was political writing 'fictional'?" (125).

16. Quoted in Pierre Michel's "Vie d'un Honnête Homme," the biographical sketch for his edition of Montaigne's Essais (Paris: Livre de poche, 1972), x.

17. The Spectator, ed. George A. Aitken, 8 vols. (New York: Longmans, 1898), 1: 1.

18. Derrida, Politics of Friendship, 21.

19. The Spectator, $1: 4$.

20. The Female Spectator, 4 vols. (London, 1744-46), 1: 3; future references will be by volume and page number. Ros Ballaster refreshingly corrects a history of critics who interpreted Haywood literally when she describes to herself as having "run through as many Scenes of Vanity and Folly as the greatest Coquet of them all" (1:2) by reminding us that "in the knowledge that during the 1720s Haywood produced a novel on average every three months, it is hard to imagine she had much time for the 'promiscuous diversions' to which she refers" (Seductive Forms, 159-60).

21. The Spectator, 1: 6. Aitkin notes in his Introduction that Steele is said to have observed that their first periodical, The Tatler, was shut down because "he had touched upon state matters, and was not so cool as to conceal his opinion" (1: xxv). See also Griffin, Literary Patronage, 106-107.

22. The biting satire of Fielding's Jacobite Journal is a model of politeness when compared with the more vicious attacks in such pamphlets as "The Highlanders Salivated" (London, 1746) and The Female 
Rebels (London, 1747), which follow in a vituperative tradition from Elkanah Settle's misogynist, antiCatholic Restoration tragedy The Female Prelate: Being The History of the Life and Death of Pope JOAN (London, 1680). See Jill Campbell's Natural Masques: Gender and Identity in Fielding's Plays and Novels (Stanford: Stanford Univ. Press, 1995) for a discussion of the brutal misogyny of many anti-Jacobite tracts in the 1740s.

23. Toni Bowers calls our attention to the powerfully positive models of female friendship and motherdaughter bonding in some of Haywood's early domestic fiction and in "The Triumph of Fortitude," a novella supposedly contributed to The Female Spectator by Elismonda. See Bowers, The Politics of Motherhood (Cambridge: Cambridge Univ. Press, 1996), 141-47.

24. We are reminded of Delarivier Manley's earlier references to "the New Cabal" or, as Gallagher describes it, "the attempt by a group of ladies to substitute romantic attachments between women for heterosexual intrigues"-a fictive construct that demonstrates how, "femaleness and fictionality strain away from politics in the very process of being filtered through it"; see Gallagher, "Political Crimes," 519-20. We should also consider the Jacobite overtones of the term "cabal" during this period.

25. The Parrot (London, 1746) is not paginated. References are therefore to issue numbers; this quote is from number 1 .

26. A yet darker overtone to the story would have been evident to eighteenth-century readers familiar with Antoine Galland's 1709 version of Les Mille et Une Nuits. It is not only the unfaithful wife who is at risk, but the honest parroting bird itself who is killed merely for reporting the adultery about which the husband does not at first believe; see the "Histoire du Mari et du Perroquet" in Les Mille et Une Nuits. Contes Arabes, trans. Antoine Galland (Paris, 1709; Paris: Garnier Frères, 1960), 49-50. Haywood, who both read and translated from French, would probably have been familiar with these stories: the ninth issue of The Parrot includes a story about a parrot stealing from a jeweler that provides an interesting variant on this tale. I am indebted to Gregory Lupton for suggesting this connection.

27. Kathleen Wilson, "Citizenship, Empire, and Modernity in the English Provinces, c. 1720-1790," Eighteenth-Century Studies 29 (1985): 69-96, 73.

28. See Thomas Lockwood's "Eliza Haywood in 1749: Dalinda, and her Pamphlet on the Pretender," Notes and Queries 134 (1989): 475-77, and Catherine Ingrassia's article, cited in note 15 above. While neither of these articles specifically labels Haywood as a Jacobite, Ingrassia has indicated in conversation with me that she also is convinced that Haywood harbored Jacobite sympathies. Ingrassia provides further analysis of Haywood's 1749 pamphlet and incisive commentary about the connection between politics and fiction during this period in her forthcoming Authorship, Commerce, and Gender in Early Eighteenth-Century England, 116-98.

29. Paul Kléber Monod, Jacobitism and the English People 1688-1788 (Cambridge: Cambridge Univ. Press, 1989), 204. I am also indebted to Miranda Burgess for many instructive hours of conversation about English Jacobitism and for her incisive reading of an earlier draft of this article.

30. For example, the Scottish Minister's A Treatise on Government (Edinburgh, 1746) rehearses in laborious detail (in the process of refuting it) the traditional Jacobite argument for the House of Stuart's lawful and natural claim to the throne. See also Monod's observation about Jacobite interest in a "minute study of the past, which symbiotically sustained an affection for the hereditary line of rulers" (287).

31. Monod, Jacobitism and the English People, 85.

32. Wilson, "Citizenship, Empire, and Modernity in the English Provinces," 69-96, 73-74.

33. Monod, Jacobitism and the English People, 96-97.

34. See Homi Bhabha's observation in The Location of Culture (New York: Routledge, 1994) that "the study of world literature might be the study of the way in which cultures recognize themselves through their projections of 'otherness.'”

35. See note 30 above.

36. See Max Horkheimer and Theodor W. Adorno, Dialectic of Enlightenment, trans. John Cumming, (New York: Continuum, 1989); and Jürgen Habermas, "Further Reflections on the Public Sphere," in Habermas and the Public Sphere, ed. Craig Calhoun (Cambridge, MA: MIT Press, 1992), 429. 


\section{Derrida, Politics of Friendship, 229}

38. Pope's now famous reference to Haywood's "two babes of love" (II.ii.158), sometimes assumed to be a purely biographical allusion but probably a reference to two of her novels that particularly offended him, not only relegated her from the political to the literary public sphere but attempted to banish her entirely from any sphere of respectable letters. The Dictionary of National Biography (1882-91) explains that the slanderous comments made about her during her own time were only revenge for the too thinly veiled allusions in her fiction to well-known figures in society. See note 15 above for a review of twentiethcentury interpretations of Haywood's import.

39. Ingrassia, Authorship, Commerce, and Gender, 125. Ingrassia goes on to suggest that "her narrative technique and multivalent voice locate the text within consumer culture and highlight the connection between politics and commerce, and the commercialization of political discourse" (125).

40. Media coverage of the friendship between former Whitehouse intern Monica Lewinsky and Pentagon employee Linda Tripp generally marginalizes and depoliticizes the two women's political roles by its focus on whether Tripp violated the traditional norms of female friendship; see, for example, Beth Frerking's "Many Perceive Lewinsky's Friend as Betrayer" (Newhouse News Service), The Plain Dealer, 3 February 1998, sec. E.

41. Although her challenges to the dominant images of friendship may not have transformed the political paradigms of the 1740s, a reconsideration of her work within the context of the revised history of friendship that Derrida describes may help us to re-envision a notion of the public good that does not depend on "all those figures of friendship... which prescribe fraternity" (Derrida, Politics of Friendship, 306). We might well ask, with Derrida: "When will we be ready for an experience of freedom and equality that is capable of respectfully experiencing that friendship, which would at last be just, just beyond the law, and measured up against its measurelessness?” (306). 